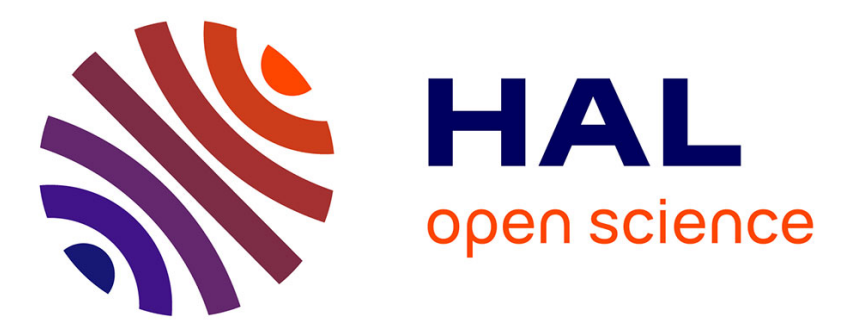

\title{
The question of sexual consent: between individual liberty and human dignity
}

David Simard

\section{To cite this version:}

David Simard. The question of sexual consent: between individual liberty and human dignity. Sexologies, 2015, 24 (3), pp.e65-e69. 10.1016/j.sexol.2015.05.002 . hal-01224871

\section{HAL Id: hal-01224871 \\ https://hal.science/hal-01224871}

Submitted on 22 Aug 2016

HAL is a multi-disciplinary open access archive for the deposit and dissemination of scientific research documents, whether they are published or not. The documents may come from teaching and research institutions in France or abroad, or from public or private research centers.
L'archive ouverte pluridisciplinaire HAL, est destinée au dépôt et à la diffusion de documents scientifiques de niveau recherche, publiés ou non, émanant des établissements d'enseignement et de recherche français ou étrangers, des laboratoires publics ou privés.

\section{(이) $\$$}

Distributed under a Creative Commons Attribution - NonCommercial - NoDerivatives| 4.0 


\title{
The question of sexual consent: Between individual liberty and human dignity
}

\author{
David Simard
}

Sexologies (2015) 24, e65-e69

Keywords: Sexual consent; Desire; Will; Sadomasochism; Prostitution; Sex work; Human dignity

Summary: In sexual matters, the concept of consent has recently come to the forefront. The concept allows a distinction to be made, notably from a legal standpoint, between what is considered to be raped and what is not. It is however a concept that is difficult to define with any clarity; its boundaries are fuzzy and it is the subject of much controversy, particularly with regard to the issues of prostitution and sadomasochistic practices (BDSM) within the ethics of sexuality. The purpose of this article is to attempt to clarify the terms of the debate. It firstly questions the foundations of sexual consent by analysing the differences or the conceptual confusion between desire and will, based initially on a reading of the philosophers of the 17th century René Descartes and Baruch Spinoza, who have opposing ideas with regard to the position of desire relative to intellect in human beings, before moving on to the psychoanalyst Sigmund Freud, who introduces the idea of unconscious desire. The article then shows that the impossibility of absolute liberty, and therefore consent free of any constraint, leads certain feminist organisations to question individual consent, even when it has been clearly formulated, and to invoke against this the notion of human dignity in a transcending sense, inspired by Immanuel Kant, the German philosopher of the 18th century. This concept is examined and studied in cases of prostitution and sadomasochism (BDSM). The conceptual analysis ultimately reveals the metaphysical nature both of the individualistic approach of consent and of the Kant-inspired approach of human dignity.

\section{Introduction}

The concept of consent is central to the ethics of sexuality. It permits a distinction to be made between what is considered to be sexual assault and what is not. Now, this is not necessarily obvious or to be taken for granted, given that there is on the one hand a concept of consent based on will or disassociated from desire (Caouette, 2015), and on the other hand a concept of consent based 
on desire, or which believes that consent to sexual relations when these are not desired is consent to forcible entry and a source of trauma (Martine, 2013). The question then arises of the value of consent, when that to which one has consented appears to contravene moral values that are upheld in society as being important. The notion of human dignity is accordingly used by some present-day feminists in order to reject consent to sexual relations with prostitutes or which are sadomasochistic. It is these two issues, that of consent being founded on desire or will on the one hand, and that of the recognition of consent through a principle of transcendence on the other hand, which will be hereafter highlighted.

\section{Some statistical data Sexual assaults}

According to the World Health Organisation (WHO), world-wide, $35 \%$ of women indicate that at some time in their life, they have been exposed to sexual violence from their partner or someone else (WHO, 2014). In the United States, according to the 2010 survey of the National Center for Injury Prevention and Control of the Centers for Disease Control and Prevention, $18.3 \%$ of women and $1.4 \%$ of men state that they have been raped sometime over the course of their life, and $44.6 \%$ of women and $22.2 \%$ of men state that they have suffered other forms of sexual violence without penetration (Black et al., 2011).

\section{The figures for prostitution}

With an entire section of prostitution dominated by criminal networks and human trafficking, and given the high ideological stakes that disrupt the principles of scientific research (Weitzer, 2005), it is difficult, if not impossible, to establish the number of people throughout the world engaged in an activity of prostitution. The figure of 40 to 42 million people practising prostitution throughout the world is sometimes suggested (Charpenel, 2012).

\section{Sadomasochistic practices and fantasies}

There are very few figures available from surveys of the general population on followers of sadomasochistic sexual practices. A 2008 study by the School of Public Health and Community Medicine of the University of New South Wales in Australia, reports that $1.8 \%$ of sexually active people stated that they had indulged in practices which can be considered as BDSM in the year preceding the survey (Richters et al., 2008). In France, there are statistical data to be found in a survey dating back to 1993 , coordinated by the INSERM (National Institute of Health and Medical Research), which sought to analyse sexual behaviour, not in terms of BDSM practices, but of the related fantasies. According to this survey, the prevalence of fantasies involving punishment and bondage was very low, from 0.5 
to $1.8 \%$ depending on the practices and the gender (Bajos et al., 1998).

\section{Consent, a matter of desire or will?}

These statistical data relate to sexual relations without con-sent and practices for which we shall look at the value of consent. The question of the foundation of consent refers back to the idea we have of human beings and of the way people interact. In a very general sense, desire is an urge directed towards something. Will could therefore very well be included under this heading, as could need, longing, wishing, etc. However, such a jumble of definitions does not permit us to think about concrete situations or to decide between what does or does not form consent.

Desire as an action of will controlled by intellect: the Cartesian approach

In the third maxim of his provisional moral code, in the Discourse on the Method, Descartes stated that he should try to change his desires rather than changing how things stand in the world (Descartes, 1953 [1637]). For him, desire comes from will, and will is only led to desire things presented to it by intellect. It is therefore possible to change his desires since desire is will, and will is itself controlled by intellect. Consent would then rest upon will enlightened by intellect and would consist in the very determination of desire in terms of the object of such desire through a rational thought process.

\section{Desire preceding intellect: the Spinozist concept}

This approach to desire, in which it is preceded by intellect, would be called into question on the one hand by Spinoza, a quasicontemporary of Descartes, and on the other hand by the founder of psychoanalysis: Sigmund Freud. For Spinoza, to be a human being is, fundamentally, to have desires. This primacy of desire in human beings derives from the fact that it is inherent in the essence of any creature to strive to per-severe in its being. Desire presents this defining feature in which it is not merely the endeavour to persevere in one's being, but moreover the consciousness of this endeavour (Spinoza, 1965 [1677]). Hence, desire precedes intellect and, contrary to Descartes, Spinoza does not believe that intellect is capable of changing desires. Desire as endeavour falling under the heading of human essence precedes any object which may be desired, and the objects which are acquired through desire are more a function of the circumstances than of a reasoned choice which might indicate to us one object or another as being desirable. Desire can therefore no longer be considered the fruit of choice. Hence, if to consent is to choose freely, desire cannot form the basis of consent. 


\section{Desire preceding intellect: the Freudian approach}

Freud would go even further. For him, the partition between desire/intellect takes the form of a partition between the unconscious and conscious mind. At the point at which Spinoza defined desire as the endeavour to persevere in one's being, accompanied by consciousness, the psychoanalyst places it firmly on the side of the unconscious mind. Desire may in fact be prevented from access to conscious mind by repression, and even the most powerful desires are unconscious, whilst nevertheless remaining active (Freud, 1968 [1915]). We can state at this juncture that if will is considered to be the result of a conscious choice, whether reasoned or not, then it is likely to be in opposition with desire, insofar as this is repressed since it is not acceptable for many different reasons. It seems under these conditions hazardous to consider that consent must be founded on desire, namely ultimately something which the person may wish to know nothing about. It seems that will, which is on the side of consciousness, is more appropriate. This does not mean that it has nothing to do with unconscious desire. But since complete self-transparency cannot be attained, it seems difficult to find a better basis for consent, which cannot be defined by a liberty, which would consist in the absence of any determinism or constraint.

\section{Individual consent called into question}

The impossibility for an individual to have absolute liberty is doubtlessly the reason for some feminist organisations to be critical with regard to consent (Abolition 2012, 2013). Another organisation for which under certain conditions, consent is not admissible: the UN. This organisation has indeed ruled that in circumstances involving trafficking, the fact that the consent of a victim of trafficking in persons to exploitation shall be irrelevant (Office on Drugs and Crime, 2004).

\section{Difficulties in evaluating the value of consent}

But, for the French philosopher Geneviève Fraisse, this is not an argument for challenging the authenticity of consent. It is in fact a complicated and perilous undertaking to seek to enter a person's inner self in order to judge the value of his/her consent (Fraisse, 2007). Another philosopher, Michela Marzano, also concentrated on the complexity of consent, where because on the one hand it is impossible to reduce a person to what that person says, and because on the other hand a person is not transparent to him- or her-self, that his/her words may be loaded with ambivalence, and that they are always spoken in a context beset with constraints and conditioning, this does not authorise us to refute his/her words by purporting to know, for him/her and better than him/her, what this says about his/her desire (Marzano, 2006). 


\section{Consent and constraints}

It is within this logic that the UN protocol seems to fall. This does not in fact hold consent in general to be irrelevant, but any consent given under circumstances such as those in which it is taken into account is judged not to be pertinent. Now, these circumstances are relatively well-defined and cover elements upheld in court to be classed as rape or sexual assault. It is therefore not enough for consent to be expressed within a context in which certain constraints prevail for it not to be taken into account; such constraints must be specific and must themselves already be reprehensible by law.

\section{Dignity over and above consent}

It is then a question of knowing to what extent an approach not independent of the person can draw on elements external to the latter in order to identify or morally condemn practices and activities implying sexual relations, even when these are consented to and where they do not constitute an offence or crime. It is here that some feminist discourses, on sex work but also on sadomasochism, invoke the predominance of human dignity.

\section{The Kantian approach to the dignity of humanity}

Dignity is understood to be conformity with a rank considered to be loaded with a reference value. The opposite of dignity is therefore any debasing of this value. It is a notion regularly invoked in ethical, and more specifically bioethical, debates, but also nowadays in the ethics of sexuality. The German philosopher Immanuel Kant often is a reference in this. He presents the distinctive idea of referring the concept of dignity simultaneously to the concepts of liberty, autonomy and respect for the subject, and to the idea of a transcendence which would go beyond any human being. He thus articulates what is nowadays found to be in a relationship of opposition, from a philosophical but also legal point of view, between on the one hand dignity regarded as an attribute of the subject which may be cited against a third party, and on the other hand dignity regarded as an attribute of humanity, which transcends people and which may be cited against them, and this even with regard to whatever they might have consented to. The Kantian approach leads us back however to the problematic idea of absolute liberty, which embeds within the subject (the individual) the value of his/her consent, which would itself be absolute. For Kant, it is this possibility for reason to apply its own law, i.e. its autonomy and its liberty, which constitutes its morality, and which forms its intrinsic value. Every human being exists, according to him, as an end in themselves and not merely as a means to be used by this or that will at its discretion. This is what Kant describes as being the dignity of human nature (Kant, 1848). 


\section{Dignity as opposed to individual liberty}

This absolute liberty is rejected by the feminists mentioned above. For them, one must start out from very real life conditions, and take into consideration the constraints that prevail under such conditions. But instead of promoting a concept of liberty and of consent as being relative, these feminist positions on the contrary introduce another form of transcendence, placed in a vision of human dignity detached from the will of the people involved, permitting the consent of the latter to be ignored, even when clearly formulated and when the level of prevailing constraint does not involve force.

\section{Transcending human dignity applied to sex work}

The application of such an approach as far as sex work is concerned has the effect of removing any distinction between sex work and rape. Accordingly, anyone who performs sex work, and this regardless of the conditions under which such work is performed, is considered to be a victim. Thus, if the problems of consent reside in the interaction between the individual sphere and the collective sphere, the transcending position of human dignity will resolve the tension between the two by taking the individual sphere out of the equation.

\section{Consent invalidated by a traumatic childhood experience?}

Generally, the individual sphere is invoked by the transcending position of human dignity in order to highlight reasons supposed to take into account the formulation of the consent and disqualify it. Abolitionist associations indeed assert that the majority of people performing sex work suffered sexual abuse in their childhood, often of an incestuous nature (cf. notably Poulin, 2003). This approach is subject to controversy (Chaumont, 2012; Lilian, 2012). But the philosophical question is to find out whether the fact of having possibly experienced sexual trauma in childhood invalidates a priori any expression of consent to sexual work at an adult age. This question extends even beyond the field of sex work and sexuality to apply to any form of consent. If we respond to the question in the affirmative, we are back to the problem raised by Geneviève Fraisse, where we are trying to judge the value of someone's consent by exploring that person's inner self.

\section{Desubjectivating human dignity}

The rejection of the concept of liberty as absolute leads abolitionists to refute any possible liberty, including non-absolutist, i.e. liberty which is hinged, even problematically, on the notions of constraint and conditioning. Human dignity then finds itself residing in the place left vacant by liberty, and is paradoxically then associated with the failure to recognise human beings as responsible subjects. 


\section{Feminist tensions with regard to sadomasochism}

The same type of issues can be found when it comes to sadomasochistic practices (BDSM).

Defence of BDSM seen from an anthropological angle, by Gayle Rubin

Debates about sadomasochism were particularly heated within American feminist movements in the 1970s and 1980s. Several radical feminists, such as Robin Ruth Linden, Diana Russell or Susan Griffin, contributed to the collective work Against sadomasochism: a radical feminist analysis (Linden et al., 1982). Several were also members of the feminist group Women Against Violence in Pornography and Media, against which the anthropologist Gayle Rubin notably protested (Rubin, 2010). The latter thus founded in 1978 in San Francisco an association fighting for the rights of sadomasochistic lesbians.

\section{Human dignity and sadomasochism: a legal approach}

It was only at the very end of the 20th century, during a process of legal reflection, that the principle of human dignity would be raised with regard to sadomasochistic practices. In 2005, the European Court of Human Rights (ECHR) considered that "the ability to conduct one's life in a manner of one's own choosing may also include the opportunity to pursue activities perceived to be of a physically or morally harmful or dangerous nature for the person concerned" (ECHR first division, 2005). The legal expert Muriel Fabre-Magnan considered that this ruling repudiated the primacy of the concept of human dignity in favour of that of personal autonomy (Fabre-Magnan, 2006). According to her, even in the case of consent, no one can validly consent to being harmed in a manner contrary to the dignity of human beings (Fabre-Magnan, 2007). There again, therefore, human dignity functions as a transcending principle, and even moves closer to its first hierarchical meaning of dignitas (social or functional rank), which more than providing entitlement to rights, confers a duty.

\section{Conclusion}

The different sides of the debate revolve around an individualistic representation of liberty versus a collective and more political, if not moral, representation of human beings. This dichotomy cannot however summarise all the possible positions, which can be and are adopted with regard to questions of consent and human dignity. By giving priority to the individual over the group for that which constitutes the very being of the individual or from the behavioural point of view, the fundamentally social condition of the human being is relegated to second place by individualism (cf. Mill, 2006 
[1843]). It is nevertheless true that there is something which exceeds and precedes each individual taken in isolation, namely social reality, which is not solely the sum of the individuals of which it is composed. But the concept of human dignity inspired by Kant reintroduces a form of transcendence of a religious or metaphysical nature, and which raises both a philosophical and a political problem for democracies, which are not merely anxious to preserve individual liberties, but also secular liberties. Consent should therefore be thought of as linking individual liberty to collective principles, both of which should be inherent to human reality.

\section{References}

Abolition 2012. Prostitution = violence $!$ Press pack; 2013

http://www.abolition2012.fr/DPprostitution-violence1.pdf

Bajos N, Giami A, Laurent R, Leridon H, Spira A. Comportements sexuels et sida en France. Données de l'enquête Analyse des comportements sexuels en France. Paris: éditions INSERM; 1998.

Black MC, Basile KC, Breiding MJ, SmithMikel SG, Walters L, Merrick MT, et al. The National Intimate Partner and Sexual Violence Survey: 2010 summary report. Atlanta: National Center for Injury Prevention and Control; 2011.

Caouette A-A.Lalonde C, editor. "Vendre son oui ». Montréal: Le Devoir; 2015. http://www.ledevoir.com/societe/actualitesensociete/433574/vendre-son-oui

CEDH première section. Arrêt 17 février 2005; 2005 http://hudoc. echr.coe.int/sites/fra/pages/search.aspx?i=001-68354

Charpenel Y. Rapport mondial sur l'exploitation sexuelle. Paris: Economica; 2012.

Chaumont JM. Le militant, l'idéologue et le chercheur. Le Débat 2012;172:120-30.

Descartes R. Discours de la méthode (1637). Paris: Gallimard, La Pléiade; 1953.

Fabre-Magnan M. Le sadomasochisme n'est pas un droit de I’homme. Conférence 2006;22:265-96.

Fabre-Magnan M. Dignité : dignité et respect du corps. In: Marzano M, editor. Dictionnaire du corps. Paris: PUF; 2007. p. 307-13.

Fraisse G. Du consentement. Paris: Seuil; 2007.

Freud S. Métapsychologie (1915). Paris: Gallimard; 1968. 
Kant E. Fondements de la métaphysique des mœurs. In: Critique de la raison pratique précédé des fondements de la métaphysique des mœurs. Paris: Librairie philosophique de Ladrange; 1848. p. $3-126$.

Lilian M. De l'objectivation à l'émotion. La mobilisation des chiffres dans le mouvement abolitionniste contemporain. Mots 2012;100:173-85.

Linden F, Pagano D, Russell D, Star S. Against sadomasochism: a radical feminist analysis. Palo Alto: Frog in the Well; 1982.

Martine J. Le viol-location. Liberté sexuelle et prostitution. Paris: L’Harmattan; 2013.

Marzano M. Je consens, donc je suis. ... Paris: PUF; 2006.

Mill JS. La psychologie et les sciences morales : sixième chapitre du système de logique (1843). Paris: L’Harmattan; 2006.

Office contre la drogue et le crime. Protocole visant à prévenir, réprimer et punir la traite des personnes, en particulier des femmes et des enfants, additionnel à la Convention des Nations Unies contre la criminalité transnationale organisée. New York: ONU; 2004.

Organisation mondiale de la santé (OMS). La violence à l'encontre des femmes : violence d'un partenaire intime et violence sexuelle à l'encontre des femmes. Aide-mémoire 2014;239. http://www.who.int/mediacentre/factsheets/fs239/fr/

Poulin R. Prostitution, crime organisé et marchandisation. TiersMonde 2003;44:735-70.

Richters J, de Visser RO, Rissel CE, Grulich AE, Smith AMA. Demographic and psychosocial features of participants in bondage and discipline, "sadomasochism " or dominance and submission (BDSM): data from a national survey. J Sex Med 2008;5: 1660-8.

Rubin G. Le péril cuir : remarques sur la politique et le SM. In: Surveiller et jouir : anthropologie politique du sexe. Paris: Epel; 2010. p. 83-134.

Spinoza B. Éthique (1677). Paris: Garnier-Frères; 1965.

Weitzer R. Flawed theory and method in studies of prostitution. Violence Against Women 2005;11:934-49. 